\title{
Alain Touraine ve Müdahaleci Yöntem -Din Sosyolojisi Bağlamında İzdüişümleri-
}

\author{
ADİL ÇiFTÇi \\ DOÇ. DR., DOKUZ EYLÜL Ü. İLAHIYAT FAKÜLTESI \\ e-posta: adil.ciftci@deu.edu.tr
}

\begin{abstract}
Alain Touraine and the Method of Sociological Intervention. The aim of the essay is to present the notion of sociology of Alain Touraine in its main aspects. Since he believes that society is no longer an appropriate object of sociological inquiries and that instead sociologists should seek social life in the individuality and singularity of each person, the most crucial aspect seems to find out the Subject/Actor in the process of sociological study. He named this process "intervention". It is this "sociology of intervention" on which we will focus to be able to appreciate the meaning of his invitation us to understand "social actors" not "society". In doing this we are going to establish some connection between our own research and his method too.
\end{abstract}

key words

"the Subject", intervention, interview, subjectivity, objectivity.

\section{Giriş}

Bu çalışmanın gayesi Alan Touraine'nin sosyoloji anlayışını ana hatlarıyla sunmaktır. Bunu; (I) derli toplu dile getirdiği bir makalesi üzerinde çözümlemeyle şahsen anlayarak; (II) Anlayıcı Yaklaşım ve Din Sosyolojisi için Uzanımları: Empirik Bir Deneme ${ }^{1}$ isimli çalışmamız ile benzeşimler arayarak; ve (III) din sosyolojisi yöntemi olabilme olanağını irdeleyerek yapmaya gayret sarfedeceğiz. ${ }^{2}$

1 Adil Çiftçi, Anlayıcı Yaklaşım ve Din Sosyolojisi için Uzanımları: Empirik Bir Deneme, Ankara: Kitabiyat, 2004. Kitaba göndermelerin neredeyse tümü s. 176-252 arasınadır.

2 Yazımız kitap bölümü olarak yazılmıştı, dergi için kısaltıldı. Umarız kopuşlar olmamıştır. 
Sonuncusunu yaparken ifadelerine ve anladıklarımıza sürekli "din" veya "din sosyolojisi" sözcüklerini yerleştirmeye girişmedik. Bunu ileride yapabiliriz. Şimdi kaçınmamız başka maksada da yönelik. O da, her sosyoloğun değilse de bazılarının üstteki sözcükleri hiç kullanmadan ortaya koyduklar1 yöntemlerin "din" konusunda da cari olabileceğini hatırlatmak. Bir araştırmacıya, "şu sosyoloğun din sosyolojisini nasıl anlatabiliriz" türünden teklifte bulunsak, bir müddet sonra gelip "tek satır bile yazmamış din sosyolojisine dair" diyebilme olasılığı yüksek. Burada ciddiye alınıp üstesinden gelinmesi gereken bir "sorun" mevcut: Toplumsal fenomenler birbirinden tamamen ayrı niteliğe sahip sanılıyor. Meramımızı daha iyi dile getirir diye örnek verelim. Peter Berger'in münhasıran din sosyolojisi sahasına ait eserlerinden haberdar değiliz, sadece Social Construction of Reality ${ }^{3}$ kitabını okuduk diyelim. Hemen hiçbir yerinde, yöntemi ile "din" arasında doğrudan irtibat kurmamış olsun. Peki ondan din sosyolojisi yöntemi çıkarsanamaz mı? Ziyadesiyle kolaylıkla çıkarsanabilir. Kitabın tezini; "Bilinçler bir eyleme yönelir, bu yönelimsellik nesnelleşir, müteakiben başka bilinçlerce içselleştirilir ve bir toplumsal dünya kurulur" cümlesiyle yazarsak; onu, "Bilinç(ler) dinsel bir eyleme yönelir, bu yönelimsellik nesnelleşir, müteakiben başka bilinçlerce içselleştirilir ve bir dinsel dünya kurulur" şeklinde yeniden yazdığımızda hem dinsel dünyanın kuruluşuna dair din-sosyolojik saptamada bulunmuş, hem onun içerisindeki dinsel fenomenleri anlama yönteminin ana ipuçlarını vermiş oluruz. Buradan ve kitabın buraya varan ifadelerinden bir "din sosyolojisi yöntemi” kurarız. Örneğin, kısaca, deriz ki: Böyle bir ontolojiye dayanan din sosyolojisi metodu mümin zihinlerin (bilinçlerin) dinsel dünya kurucu anlamlandırmalarını anlamak isteyeceğinden, derin yorumsamayla bilinçlerin anlam tabakalarına girmek zorundadır. Ve uzun uzun bunun yolları, çekinceyle kullanıyoruz terimi, 'teknikleri' anlatilır.

Aynısı Touraine için de geçerli. Sosyoloji anlayışı ve yöntemi din sosyolojisi gibi okunabilir. Kaldı ki, çözümlediğimiz metnindeki "din" atıfları bu okumaya telmihte bulunmaktadır da. Nilüfer Göle de zaten bunu yapmıştır. Tam uzlaşamadıklarını bizzat Göle'nin ağzından duyacaksak da, bu bile din sosyolojisi bakımından bir imkanı telkin etmekte. Ayrıca, ondan bağımsız bakıp irtibatlandırma çabasıyla Touraine'nin yazısını okuyunca, kendi din sosyolojisi anlayışımız ile hayli örtüştüğünü; temel felsefî varsayımların neredeyse aynılığını, neyi ve nasıl araştırmak gerektiğine dair tekliflerin

3 Türkçe güzelliği için teşekkür vesilesi kılarak: Peter L. Berger \& Thomas Luckmann, Gerçekliğin Sosyal İnşası, çev. Vefa Saygın Öğütle, İstanbul: Paradigma, 2008. 
ise tamamen aynılığını da gözlemledik. Hülasa, onun sosyolojisi aynı zamanda din sosyolojisidir demek hayli mümkün.

Bahsettiğimiz makale "hermeneutik bilinç" gerektirmekte: sözcüklerin ilk anda çağrıştırdığı anlamlara kuşkuyla bakıp derinlemesine anlamayı lüzumlu kılmaktadır. Teknik terimler/ıstılahların gündelik hayat lisanından farklı anlamlarda kullanılabildiği epeyce bilindiğinden; sıradan bilimsel bilinç dahi onlara dikkat eder. Buna bile her zaman dikkat gösterilmediği elbette bilindik keyfiyettir. Anlamını anladı̆̆ımızdan şüphe duymazmış gibi, terimleri araştırma ve çevirilerimizde nasıl da yanlış istihdam ettiğimizin misali az değildir. Touraine'nin makalesinde asıl tehlike; bazen sıradan kelimelerin de aşina olunmayan ve tek bakışta farkına varamayacağımız anlamda ve gayet bilinçli kullanıldığının; bazı gramer hataları bulunduğunun; kelime oyunları yapıldığının ayırdına varamamaktır. Derin anlama belki en fazla bunlarda kaçınılmazdır. Metnimizde bunun örnekleriyle karşılaşılacaktır. Örnekleme kah dilsel analizle, kah çevirinin yanına aslı yazılarak gerçekleşecektir.

Touraine'nin yalnızca"A Method for Studying Social Actors" ("Toplumsal Özneleri İncelemek için Yöntem") ${ }^{4}$ başlıklı yazısından çıkarsadığımız yaklaşımı anlayabildiğimiz kadarıyla aşağıdaki gibi anlatılabilir. Anlatımda koyduğumuz alt başlıklar biraz yapay kalabilecektir.

\section{Sosyolojinin Özgün ve Özel Yöntemleri}

"Sosyoloji yapmanin ne demekliği" hususunda bile tam uzlaşım yokken özgün ve özel metotlarını belirlemek sanki olanaksız görünmekte diyen Touraine, elemelerle başlar işe. İki yaklaşımı karşılaştırmakla ve eleştirmekle gerçekleştirecektir bunu.

Toplumsal-iktisadî araştırmalardaki "niceliksel çözümleme"ye ihtiyatla yaklaşılmalı öncelikle. O, "toplumsal statü" ve "ekonomik-toplumsal davranış" bağıntısı kurarak "sistemin mantığı"na dair bilgi verebilirse de; "aktörlerin mantı̆̆ı", "aktörlerin davranış gerekçesi” hakkında sessizliğe bürünür. Sosyoloji bununla eşleşemez diyenler; özgür, en azından özerk özne'ye; çevresini ve kendi durumunu değiştirici, tasarımsal dünyalar kurucu, mutlak veya aşkın değerler ile irtibata yetenekli, ve de muhabbet ilişkilerine girebilen varlık niteliğiyle "aktör"e ulaşmak üzere başka yöntem(ler) kurmalıyız, derler. ${ }^{5}$ Böyle edim ve eylemlerde bulunabilen aktör'e ulaşma-

4 Alain Touraine, "A Method for Studying Social Actors", Journal of World-Systems Research, Fall/Winter 200, 900-918, Special Issue: Festcchrift for Immanuel Wallerstein-Part II http:// csf.colarado.edu/jwsr. Bundan sonra, Touraine, "A Method".

5 Touraine, "A Method", s. 900. 
yı başarabilmede ve analiz zeminine yerleştirebilmede "tarihsel tahlil tipi" gerekir diye ileri sürerler. Kültür tarihi, bazen isimlendirildiği gibi tarihsel antropoloji bunu kullanır. Bu yaklaşım, ekonomi tarihine ve siyaset tarihine benzer biçimde, genel ve özel yöntemler tatbikiyle, büyük birimleri veya bütünleri "evrim süreci içerisindeki" kültürler veya merhaleler addeder. ${ }^{6}$

Fakat, sosyoloji; sosyal veya ekonomik "bütünler"in ("ensembles") "iç mantığı/yapısı"nı ("inner logic") keşfettiğini öne süren böyle bir "tarihsel yaklaşım" ile de eşleştirilemez.

"Bütünler" ile karşıladığımız "ensembles" sözcüğü şuurlu istihdam edildiyse, Touraine o yaklaşıma muhalefetini veya onu yetersiz bulduğunu tek başına onunla dahi gösterebilmekte. "Ensemble" burada "bütünler" şeklinde çevrilip bırakılırsa gösterme gerçekleşemez. Mânâsına biraz derin bakmalı: "Parça veya unsurların bütün teşkil ediyormuşcasına birlikte algılanması." Yani, demek istiyor Touraine, bu yaklaşım "sosyal bütünler" veya "ekonomik/iktisadi bütünler" tabirlerini kullanırken aslında onlarda bulunmayan "bütünlük" vasfını sanki varmış gibi yüklüyor onlara. Bu çözümlemede yanılmadıysak, tam haliyle cümle şöyle çevrilmeli: "Fakat, sosyoloji, aslında bütün oluşturmayan ama öyle algılanan sosyal veya ekonomik bütünlerin iç mantığını keşfettiğini ileri süren böyle bir tarihsel yaklaşımla da eşleştirilemez."

Demek, sosyoloji kendini ne "rasyonel davranışın incelenmesi" ("ekonomi"); ne "bir toplumun veya muayyen bir kültürün içsel mantığının incelenmesi" ("kültür tarihi ve tarihsel antropoloji") ile kısıtlayabilir."

Bu ikili eleme sosyolojinin klasik tanımına götürür bizi. O ya bir toplumsal düzende, ya toplumsal değişim sürecinde yahut da her ikisi addedilen bir sosyal çerçevede meydana gelen, iki veya daha fazla aktörün kurduğu anlamlı sosyal ilişkilerinin incelenmesidir. Tanımda anahtar "anlaml sosyal ilişkiler" tabiridir ve Weber'e borçluyuzdur. Bu ve benzeri klasik tanımlar, "aktör/özne olarak toplumsal birey"e hakkını vermede Touraine'ye hazır dayanak sunmakta. Aynı tanımda "toplumsal düzen" ${ }^{8}$ kavramının da kullanıldığına bakılınca ve bu da benimsendiğine göre; özgür aktörler tarafından kurulan münasebetlerin iki açıdan sınırlılığını da kabul ediyor. Birincisi; insan her istediğini yapabilecek ölçüde özgür değildir; sınırsız, normsuz ve kurumsuz; kısaca, "düzensiz" toplum yoktur. Katıksız "yeni-icad" ("creative") sosyal ilişkiler de mevcut değildir bundan ötürü. İkincisi; insan

6 Touraine, "A Method", s. 900.

7 Touraine, "A Method", s. 900.

8 Göreceğimiz üzere, "toplumsal düzen"in pozitivist kullanımına itirazı vardır. 
davranışları sıkı sıkıya determine ediliyor da sayılamaz. İkisini birlikte ele aldığımızda bir tür Durkheim ve Weber terkibi okumak mümkün.

Münhasıran Durkheim izlerini okuduğumuz birincisi ontolojik tespittir ve anlamı aşikardır: insanın her istediğini yapabilecek ölçüde özgür olduğu; sınırı, normu ve kurumu olmayan; sosyal ilişkilerin her keresinde sil baştan (yeni-icad) kurulduğu bir toplum bulunamaz; varsa, ona "toplum" denemez. Weber kaynaklı olabileceğini anladı̆̆ımız ikincisi ise önce insandoğasal, sonra epistemolojik, ve sonra da yöntemsel tutumdur ve anlamı şudur: Toplumsal eylemin doğuşunun dayandığı niyet, maksat, gaye, hedef ve bunların temelindeki değerler yalnızca dışsal normlara; toplumda genel olarak onaylandığ farzedilen düşünme ve yapma tarzlarına indirgenemezler. Onlar tamamıyla egemen olsalardı hiçbir sapma, ayrılma, ibda, bireysel talep ve değişme meydana gelemezdi toplumsal hayatta. ${ }^{9}$

\section{Sosyolojinin Özel Alanı}

Sosyo-ekonomik ve sosyo-tarihsel araştırmaların ehemmiyetini reddetmeksizin sosyolojinin özel alanını kabataslak ve başlangıç kabilinden belirleyebiliriz böylece: Toplumsal determinizm ve özgürlük; toplumsal (dışsal, nesnel) normlara atıf ve insanî (öznel, içsel) anlamlandırmalara atıf; kurumsal düzen (inançlar, kabuller vs.) ve istençlice (voluntarily) ondan sapan davranışlar arasındaki iliş̧iler. Başka söyleyişle; sosyolojinin özel alanı, hem determinizme hem özgürlüğe, hem umumi normlara hem kişisel anlamlandırmalara, hem kurumlaşmış düzene hem ondan istençli sapmalara atfı gerektiren bir "karşılıklı ilişkiler sahası"dır.

Şu halde, ayrı disiplin niteliğiyle "sosyoloji"nin ilgisi aktörler ve iletişim konusuna yönelecektir. Üstteki yaklaşımlar sistemlerin mekanizma ve organizasyonları ile meşgulken; ${ }^{10}$ sosyoloji, aktörlerin bir taraftan onlar ile, diğer taraftan birbirleri ile "iletişimini" inceleyen bilimdir.

Toplumsal davranışı iktisadî nitelikte bir rasyonel tercihe, "belirleyicisi" ("determinant") sayılan kültürel örüntülere ve toplumsal kurumlara dayandıran yaklaşımlardan ırak durunca şu soruyla karşı karşıya geliriz hep: Yerleşik normlardan uzaklaşma nasıl oluyor da yaratıcı özgürlüğe, yaygın kuralların reddine, "toplumsal dişı düzenlenen (bireysel)" ("non socially regulated") hislere ve, nihayet, yeni normlar üretilmesine götürebilmektedir? Bu soru toplumsal iletişim ve iletişim ilişkisi biçimlerinin "değişim üretici" yapısı dolayısıyla merkezîdir ve "sistem dışı(nda) aktör" ("the actor

9 Touraine, "A Method", s. 901.

10 Touraine, "A Method", s. 901. 
outside the system") vurgusunun bariz işaretidir. ${ }^{11}$ Bize öyle geliyor ki; bu, iletişimin doğasıyla da yakından alakalıdır.

Asıl mesaj konuşanların karşılıklı etkileşimi süreciyle ve sürecinde farklılaştığı, algısal ayrılığa uğradığı oranda ancak "iletişim" vardır. ${ }^{12}$ Touraine burada "the interaction between the speakers" diyor. Bunu yukarıdaki gibi çevirdik ve sırf "bireyler arasında konuşma" $y ı$ andırıyor sanılabilir. O, aynı zamanda, "kurumlar/kurallar" ile "bireyler" arasındadır. Bu anlamda bir "konuşmacılar arası karşılıklı ilişki" ve getirebileceği farklılaşmalar, algı ayrrlıkları olduğu müddetçe ancak iletişimler kurulabilir. Bütün toplumsal iletişim ve ilişki biçimleri "değişim üretir" deme nedeni budur Touraine'nin.

$\mathrm{Bu}$ tanımlama gündelik hayat bilgimize ve sosyal bilimlerdeki genel kanaate neredeyse tamamen terstir. İkisinde de; "iletişim" aynı mesajı aynı tarzda algılayanlar hattında olanaklı sanır, farklılığın iletişımi olanaksızlaştırdığını kabullenme eğilimi taşırız. Şimdiki görüşe göre ise, bu bir iletişim, karşıllıklı konuşma veya diyalog değil; insan sayısı çoksa da bir mono$\log$, bir "kendin söyle kendin işit"tir. Bir "kendin çal kendin oyna"dır.

Bunu din sosyolojisi açısından yazarsak; "iletişim"den kasıt, örneğin "Ana Mesaj/Kur'an" ve "yerleşik kurumlar" (geleneksel düşünceler, inançlar vd) ile bireyler arasında; yine bireyler arasında ama "Kur'an" ve "kurumlar" hakkındaki iletişimdir. Çalışmamızda bunun örneklenimini bulduğumuz kanaatindeyiz. Anlamıştık ki, özne-konularımız (aktörlerimiz), kural ve kurumlarılla kurduğu dünya ile "Gelenek"i uzun bir "monolog" görüyor ve uzunluğun daha da uzamasını istemiyorlardı. Bu "monolog" yeterinden fazla sürmüş, özne/aktör bireylerin hayatını "monodram"a çevirmiştir artık. Tek başına çekmek zorunda kaldıkları ıstıraplar yumağına yani. Ve bu uzun sürüş, sırf uzun sürüşlükten dolayı pek çok insanı geleneğin monoloğunu meşrulaştırma ve tek kişilik varoluşsal dramlarının meşruluğu konusunda ikna da etmiştir. Metn'in/Kur'an'ın ve ona dayandırılan geleneğin üzerinden "çok zaman geçmişlik" başlı başına sağlam gerekçe gösterilmiş; "Ben varım, ben de varım ve ben buradayım" seslerinin kısılması dinsel kitaplara bağlanmıştır. Çünkü bu hıçkırmaların kitapta yeri yoktur. Onlar bunu da sorgulamaktaydılar. Özneler-arası iletişimin asıl mesajın karşılıklı etkileşimler yoluyla algısal farklılıklara maruz kaldığı oranda mevcutluğunu kabulle kalmayıp, bizzat asıl mesajın varlığını devam ettirmesinin de böyle olanaklı olduğunu ileri sürüyor gibiydiler. Daha mı keskin ifadeye büründürelim; onlar, bizzat Kur'an'ın sırf kendine konuşuyor olmaklıktan çıarıl-

11 Touraine, "A Method", s. 901.

12 Touraine, "A Method", s. 901. 
masını talep ediyorlardı sanki. Kur'an ile ama aktör vasfiyla kurdukları toplumsal iletişim ve ilişki biçimlerinin "değişim ürettiğini” ileri sürdükleri söylenebilir bu nedenle.

"Her iletişim değişim üretir" önermesi nasıllığını anlatmaz pek. Bir diyalektiğe işarettir yine de. Değişim birbirini tamamlayan iki yolla vuku bulur: Yerleşmiş normların yıkılması, yenilerinin inşası. Öyleyse, Sosyoloji ne sosyal normları hiç hesaba katmayan "aşırı etkileşimciliği", ne de değişimi dış koşullanmaya bağlayan "aşırı sosyolojik determinizmi" kabul edebilir. Bu yüzden sosyolojide ana mesele, "düzen" ve "değişim", "itaat (uyum)" ("conformity") ve "çizgidışılık" ("creativity") uçlarını biraraya getirebilmektir. ${ }^{13}$ "Düzen" ve "değişim"i birlikte düşünmektir.

Çalışmamızda bunu başarabildiğimizi düşünüyoruz. Bir taraftan; aktörlerin hem Kur'an dahil gelenek ile karşılıklı konuşma pozisyonu alarak, hem de gelenek hakkında birbirleri ve içinde bulundukları "zaman" ile karşlıklı konuşarak "ana çizgi”yi korudukları (uyum) düşüncesinde olduklarını görüledik. Diğer taraftan ise, "ana çizginin, yani mesajın eski tezahürünü" kabul etmeyip "yeni tezahür" (değişsim) talep ettiklerini.

\section{Sosyolojinin Amacl}

Sosyolojinin amacı "düzen" ve "değişim"i birlikte göz önünde tutmaktır. $\mathrm{Bu}$, onun, toplumsal aktörleri statülerine, oynadıkları veya oynamaları beklenen rollere göre tanımlayışlardan niçin gittikçe uzaklaşması gerektiğinin gerekçesini de verir. Bu uzaklaşmanın niteliği; "sistem-odaklı sosyoloji" ("system-oriented sociology") telakkisini bırakıp, "aktörün sosyal durum tasavvurlarını (anlamlandırmalarını, tanımlarını, projects)" öne alan "aktör-odaklı sosyoloji" ("actor-oriented sociology") telakkisine geçiştir. ${ }^{14}$ Zira, aktörlerdeki sosyal durum tanımları "bütünleşme" ve/ama "kendi kimliklerini savunma" arzusunu çok ters biçimde birleştirir. ${ }^{15}$

Bu uzaklaşma "işlevselcilik" ("sistem-odaklı") ve "etnometodoloji" ("aktör-odaklı") uzaklaşmasıyla neredeyse aynıdır. Touraine, Etnometodoloji gibi, aktörün bir yandan normlarla uygunluk içerisinde olduğunu düşündüğünü, diğer yandansa bireysel kimliğini vurguladığını ileri sürmektedir. Sosyolojinin de, bundan dolayı, aktöre yönelerek aynısını yaptığını söylemekte ki, Sembolik Etkileşimcilik esinli Etnometodoloji yoluyla bizim yaptığımız da buydu. Onun "aşırı etkileşimcilik"i eleştirdiğine bakıp, "sembo- 
lik etkileşimcilik"i reddettiğini düşünmenin hata olacağı kanısındayız. SE'nin temel tezini benimsiyor gözüküyor. Bu da, kısaca hatırlatırsak; "aktörlerin kendi hayat durumlarını yeniden üretebildikleri veya üretme isteği taşıdıkları"dır. Bunun başka yolla söylenişi; aktörlerin kendi durum tanımlarını kendilerinin yapma isteğinin yeni durumlar üretebilme potansiyeli taşıdığıdır.

Özellikle Etnometodoloji ile bağlantı açısından söylersek, Touraine şuraya varıyor galiba: Aktör, anlamlı toplumsal ilişkilerinde, davranışlarını anlamada ve başkalarına anlamlı kılmada metodoloji yapar. Bu "profesyonel olmayan metodoloji", profesyonele de (meslekten sosyologa da) metodolojinin nasıllı̆̆ını verir. O kimliğini, benlik imgesini vurguluyorsa, sosyolog da vurgulamalıdır. Buraya eklememiz gereken, aktörün benlik alg1s1nı ön plana çıkarmasına ve, böylece de, ister istemez bir sapma meydana getirmesine rağmen, süreç içinde yeniden (toplumsal) bütünleşmeye gayret ettiğidir. Kendisinin de itirafı üzere, sosyal psikolojiye epeyce yaklaştık. $^{16}$

Touraine bunu yapmasa da, bu tür yaklaşımlarda sosyal psikolog G. H. Mead'e sıklıkla müracaatın nedeni budur. Belki şu noktada Mead'den ayrılıyor Touraine: Aktörler kurallara ve normlara itaatleriyle değil, kendi kendileriyle ilişkileri, kendilerini aktörleştirme yetenekleri, çevrelerini değiştirme kabiliyet ve güçleri; ve de özgürlüklerini takviye kudretleri ile tanımlanırlar. Kurallar ve oluşturdukları durumlar ile aktör arasında tam "uygunluk veya mütekabiliyet" ("correspondence") olmadığını bu kabul ediş, sosyolojik çözümlemede kökten bir değişime götürür bizi. ${ }^{17}$

İstikrarsızlık Iilkesi

Touraine, çalışmamızda sakındığımız, sakınırken kendisine de dayandığımız bir tutumdan söz eder: Sosyal davranışı "zıtlıklar açısından" ("in terms of oppositions") tanımlamaya alışmışız. Bu da şu veya bu şekilde "gelenek" ve "modernite" arasında varsayılan zıtlığa denk düşürülür. Bu tutum, sosyal aktörü anlayabilmenin onu ya "gelenek yakası"na ya da "modern yaka"ya yerleştirmeyi gerektirdiğini telkin eder israrla. ${ }^{18}$ Onun yöntemsel yanlışı, dışarıdan "durum tanımlaması" yapması, aktörlere dışarıdan kategori yüklemesidir. Yüklenilen kategorileri bir yana koyup "durum tanımını" bizzat yapan aktöre geçersek, bir toplumsal organizasyon veya bir norm

16 Touraine, “A Method”, s. 902

17 Touraine, "A Method", s. 902.

18 Touraine, "A Method", s. 900-901. 
hakkında tavrını "istikrarsızlık ilkesi" ("the idea of ambivalance") ile tanımlarız. "İstikrarsızlık"1 sosyolojik yöntemin odağına yerleştirirsek, aktörü tarihsel, ekonomik veya sosyal açıdan tanımlanmış bir durum ile, böyle bir "durum tanımı" ile özdeşleştirmenin olanaksızlığını ifade eder. ${ }^{19}$

Sosyal aktör mütemadiyen karışık, istikrarsız hisler içerisindedir. Bir genel duruma ve kategoriye yapışık değildir. Kendisine mahsus tanımlamalarından dolayı iki arada bir derededir: yüklenilen yahut yerleştirildiği durum tanımını veya konumu hem kabullenir hem reddeder. Bundan ötürü; biz sosyologlar da bir durumu "dışarıdan" ("objective") ve "kuralsal" ("normative") tanımlayan "terakki", "modernleşme", "düzen" ve öbür kategorileri hem benimser hem benimsemeyiz. Aynı zamanda, aktörün durumunun bütün yönleriyle ilgili "istikrarsıılığını" ve ilgilerine, kişiler arası ilişkilerine veya değerlerine yapılan atıf türünü yeniden inşa ederiz. ${ }^{20}$

Yukarıda geçen "biz sosyologlar da" yerine yalnızca "biz" zamiri kullanılmakta metinde. Cümlenin yukarısı ile irtibatla yetindiğimizde, "biz"in bir anlatı üslubu olup şahsımıza değil de haklarında konuştuğumuz kişilere işaret etmesi mümkün olduğundan "aktörlere" göndermede bulunduğu kabul edilebilir. Fakat, "ve" ile başlayan cümle tamamen anlamsız düşer. Bundan dolayı, o pasajları önceki ifadelerin genel anlamı ile irtibatlandırdığımızda şunu söylemek olanaklı: Touraine bir yöntem teklifi yapmakta ve onun odağı, aktörlerin bir tür "istikrarsızlık içerisinde olduklarını" kabul etmektir, çünkü aktörler öyledirler; bir "kategoriyi" hem kabul eder hem reddederler. Ama onlarla özdeşleştirilemezler, "kendilerine mahsus tanımlamaları" vardır. İşte, diyor Touraine tam da "gündelik hayat sosyoloğu" gibi, biz sosyologlar da aynısını yapmalıyız. Başka bir söyleyişle; "istikrarsızlık ilkesi" bizim için de geçerlidir; fakat "aktörlerin kendilerine mahsus tanımlamalarını" öne çıkarmalıyız. Çünkü bireysel durum algıları söz konusudur ve ilgileri, değerleri ile tanımlarlar durumları. ${ }^{21}$

"İstikrarsızlık ilkesi"nin, iki haliyle de, bahsettiğimiz araştırmamızda kendini gösterdiği söylenebilir. Fakat, din sosyolojisi çalışması olduğundan belki, biraz farklı ifadeye bürünüyordu. Kısa anlatılması kolay değilse de, deneyelim. "Geleneksel durum tanımları/kategoriler" ile başlayalım. Onların tamamen kenara konulduğu anlamalarımız arasında değildi. Ne var ki, aynen onaylandığı da ortaya çıkmadı. Sunulan gerekçe Touraine'-

19 Touraine, "A Method", s. 903.

20 Touraine, "A Method", s. 903.

21 Touraine, "A Method", s. 903. Metinde yine gramer hatası var gibi, fakat umumi bağlama bakıldığında böyle anlayabiliriz görünüyor. 
ninkiyle benzerlik taşır: Dışarıdan ve kuralsal yapılan tanımlamalar "birilerince konulan kategoriler"dir. Geleneğin yaptığı durum tanımları "birilerini" yansıttığından, "kendilerinin biriliklerini" (kendilerinin aktör sıfatıyla durum tanımlarını veya algılarını) hesaba katmamaktadır. Halbuki kendileri, birilerinin yanında ama başka birileridirler. Bu ilke Kur'an söz konusu olduğunda bile açığa çıkmaktaydı. Bir yandan; mesela, Kur'an'ın "hanımlar" hakkındaki durum tanımları veya onların durumlarının Kur'an tarafindan tanımlanması kabul görüyordu. Diğer yandan ise, bu tanımların "anlamlar"a veya "ilkeler"e işaret ettikleri fikri benimseniyor, "lafızların" ilkelerin tam dişavurumu olduğu reddediliyordu. Bunun gerekçesi olarak anladığımız şuydu: Tanrı mesaj olarak herkese ve bütün zamanlara konuşmuşsa da, "birisine" ("peygambere") ve "birilerine" ("ilk muhataplara") hitap etmiştir öncelikle. Ve Tanrı "tarih üstünden" fakat tarih içerisinde tarihe (topluma) konuştuğundan, muhatapları arasında diğer zaman ve mekanlardaki "birisi" ("birey") ve "birileri" de ("farklı toplumlar" da) bulunmalıdır. O halde, Kur'an'ın "durum tanımları" (örneğin hanımlara ve kölelere dair bütün hukuksal tanımlamalar) lafız itibariyle "ilk muhataplarla uygunluk içerisinde" bulunsa ve onların algılarına denk düşse de, kendi alg1larına denk düşmemektedir. Ne var ki, kendilerini "modern kategorilere" de tamamıyla uyumlu hissetmiyorlardı. Bu anlamayı sosyolog açısından ifade edersek; Touraine'nin dediği gibi, onlar yalnızca günümüzle alakalı kategorilere yerleştirilememekle kalmazlar, tarihsel durum tanımlarına da zorlanamazlar. Başka türlü söylersek; sosyolog onları ne "günümüz durum tanımları", ne de "geleneksel durum tanımları" ile birebir kategorize edebilir.

Sosyal davranışı "zıtlıklar açısından" tanımlamayan bu bakış diyor Touraine, "niceliksel araştırmalar" 1 hakimiyetindeki uzun dönemden sonra"niteliksel araştırma yöntemleri"nin niçin revaç kazandığının gerekçesini de ortaya koyar. Nicel araştırmalar sosyolojide değilse de iktisadi çözümlemelerde vazgeçilmezdir. Çünkü, belki mecburen, iktisadi davranışın tiplerini ayırdıklarından, "aktörün projesi"ni yeniden kurma hedefi zaten gütmeyebilirler. Halbuki sosyolojideki "niteliksel incelemeler" aktörlerin "projesini, tasarısını, algısını" öne alır, yeniden inşa eder; onlara dışarıdan yüklenilen 'plan-projeler'i uygulamaya çalı̧̧maz. ${ }^{22}$

\section{Toplumsal Eylem ve Anlamı}

Touraine'ye göre, toplumsal eylemlerde ve toplumsal iletişim süreçlerinde bir "sosyal-olmayan ilke" mevcuttur: eylemde ve iletişimde bir nevi "itaat- 
sizlik veya uyumsuzluk", "yenilikçi talep" ve "toplumun kurum ve kurallarının sınırlanması isteği”" vardır. Bu belirleme aşırıdır, belki ifrattır ve bizi sosyoloji alanından çekip "ideoloji alanı"na ve aktörün "öznelliğine" yerleştiriyordur. Ama "sosyal eylem"in başka temel niteliği zaten yoktur ki. ${ }^{23}$

Touraine'nin yukarıda verdiği klasik sosyoloji tanımı gibi, "toplumsal eylem"in bu özelliği de hem tek başına Weber'i, hem de anlayıcı paradigmanın tümünü yansıtıyor. Bizzat tırnak içine aldığı "ideoloji alanı" da aynı çerçevede düşünülebilir. Çünkü, neredeyse eminiz, "ideoloji" ile bireylerin "anlamlandırma çerçevelerini" kastetmekte. Böyle bakıldığında, Weber'in hatta Marx'ın yaptığı birer "ideoloji çözümlemesi"dir. Büyük fark şudur: Weber, eylemlerde aktörlerin "içeriden saikleri"nin etkili olduğunu söylerken; Marx davranışların dışarıdan ideoloji yüklemeleriyle yapıldığını söyler. Onları birleştiren önemli bir nokta da var. İkisi de eylemin "açık fiziksel hareket" içermeyebileceğini düşünür. Örneğin, ikisi için de, "rıza gösterme" böyledir ve belli ideolojileri yansıtırlar. Fakat yine ayrılırlar: Marx'a göre bu bir "yanlış bilinç", Weber'e göre yalnızca "bilinç"tir. Birincisi diş kaynaklı, diğeri iç kaynaklıdır. Din sosyolojisi açısından konuşursak; Weber'e göre, dinin kaçınılmaz işlevlerinden biri "kötüye rıza göstertip onu meşrulaştırma" ("teodise") iken; Marx'a göre, dinin en kötü işlevi insanlara gerçek durumlarını unutturup rıza göstermeye iten bir "yanlış bilinç" oluşturmasidır.

Yukarıdaki kısa karşılaştırma bir yana; Touraine, Weber ve diğer anlamacı yaklaşım taraftarları gibi, toplumsal eylemi anlamak için evvela "anlamlılı̆̆ını" kabul etmek gerektiğini düşündügünden, aktörlerin öznelliğine, "ideoloji alanına" girmenin lüzumunu benimsiyor ve başka yolun da bulunmadığını söylüyor. Bundan dolayı, sosyolojik araştırma her ne ise, bir "sosyal-olmayan ilkeye" başvuruyu veya atfı açığa çıkarmalı hepsinden önce. Mamafih, beklenecek şu soruları da sorar: "sosyal-olmayan bireysel ilgi ve ilkeler" sosyal norm veya ilkelere üstün mü tutulmalı; onlar toplum normlarını hem dönüştürecek hem de yerlerinden edip yerlerini mi alacaklar? Yanıt olumsuz verilmekte. Çünkü eylem veya davranış, özellikle toplumsal-anlamlı davranış ise, pek nadiren sırf bireysel ilgiyle ifade edilebilir. ${ }^{24}$ Yalın bir örnek veriyor: kişisel ilgilerini, menfaatlerini savunuyor gözükenler büyük bir toplumsal tehlike karşısında hayatlarını feda edebilirler pekala. $^{25}$ Demek istediği ve araştırmalarında tespit ettiği husus tam bu 
değildir ve "sosyal davranışın toplumsal olmayan ilkesi"nin böyle yorumları tatminkarlıktan uzaktır.

Dediği; araştırmamızdaki metinleri anlarken farketmekle kalmayıp dile de getirdiğimizdir: aktör, normları ve kurumları ne kadar çok öz saygısına, izzeti nefsine, onuruna, haysiyetine tehdit hissederse; o kadar çok "adaletsiz" ve "gayri meşru" görür onları. Gittikçe artan şekilde şöyle düşünmeye başlamıştır: "Toplumsal kurallar aslında toplum yararına ve tüm insanlığın faydasına oluşturulmuş değildir; bilakis, insanların özgürlüğünü, sorumluluğunu ve onurunu tehlikeye atan iktidar tezahürleridirler." ${ }^{26} \mathrm{Bu}$ ifadelerin Marx'ı işaret ediyorluğunu düşünebilmek bir yana, araştırmamızın aktörlerinin "Din ve Meşrulaştırma" ile ilgili soruya cevapları büyük ölçüde aynını söylüyordu. Bizim sosyolojik yorumla muhtelif yerlerde dile getirdiğimiz de aynı kapıya çıkmakta. Buna göre; insanlar "gelenekli dinsel hükümleri" sırf "geleneksel" diye değil, onurlarını zedelediklerini düşündükleri taktirde onaylamazlar. Normlar, kurallar, kurumlar toplumsal ve yaygınlıkla benimsenmiş olabilir. Ama "bazı insanlar" onları bir iktidar tutkusunun tezahürü algılayıp "adaletsiz" de bulabilirler. Bu Kur'an için de geçerli görünmüştü araştırmamızda. Hatırlatalım; aktörler Tanrı'nın "adaletsiz davranmayacağına" inanmakla birlikte; Kur'an'daki bazı hükümlerin literal uygulanmasının ister istemez bu sıfatın yakıştırılmasına hatta yapıştırılmasına yol açacağını düşünmekteydiler. Bazıları geleneğin O'nu tam da böyle 'adaletsiz' gösterdiği fikrindeydi.

\section{Müdahaleci Yöntem}

Yukarıdaki belirme ve belirlemeler sosyolojinin özgün yöntemlerinden birinin zeminidir. Sosyoloğun hedefi, toplumsal normların otoritesi namına, kurumların korunması hatırına ve iktidar sahiplerinin arzusu adına bastırma ve baskıdan (repression) ötürü üstü örtülen talep, istek, çekişme, çatışma ve tartışmaların üzerini açmak ve onları bilinç dışına ittirmektir. "Sosyal-olmayan ilke"ye gönderim ne tamamen "bilinçsiz" (analizleri keyfî yapard1), ne tamamen "bilinçli" (sosyolojik araştırmayı "görüşler incelemesine" indirgerdi) olduğundan; sosyolog ilk anda gözükmeyen ve kuvveden fiile geçmemiş (latent) davranış ve uygulamaları açı̆̆a çıkartacak (unveil) kadar aktif olmalıdır. ${ }^{27}$

Biz sosyal bilimciler, diyor Touraine, sosyoloğun rolünü umumiyetle "pasif" görme eğilimindeyiz. ${ }^{28}$ Halbuki aktörlerin yukarıda bahsedilen "de-

26 Touraine, "A Method", s. 904.

27 Touraine, "A Method", s. 904.

28 Bu cümle (:) ile kesiliyor. Noktalama işaretlerinin Türkçe'de kullanılışı açısından bakıldı̆̆ında, 
rin" hislerinin en iyi dışavurulabileceği koşulları oluşturacak olan sosyologun bizzat kendisidir. Bu, varsa, kurumlaşmış normların etkisinin gözlemlenmesine de genişçe kapı aralar. "Soğuk" ortamda yürütülen araştırma ancak uyumcu davranışın varlığını ve önemini gösteren sonuçlar üretir çoğunlukla. ${ }^{29}$

Bunu biz şöyle ifade etmiştik. Niceliksel araştırmalar davranış, düşünüş ve uygulama biçimlerini din kitaplarından alıp "dindarlık ölçüsü" koyduklarında ve bir "soğuk ortamda" soru sorduklarında; deneklerden olumlama gelmesi son derece muhtemeldir. Halbuki, bireysel varoluş meselesi şeklinde karşılaştıklarında veya karşılaştırıldıklarında aynı kişilerin farklı hükümde bulunmaları, mesela çok eşlilik konusunda olumsuzlayıcı bir "hayır" demeleri pek olasıdır. Öyleyse, 'gözlem' için, yalnızca zaman ve mekanı seçerek değil, doğrudan "müdahale ederek" yeterli ortamı yaratması gereken sosyoloğun kendisidir. Böyle bir vasatta şahsen teşvik, sevk ve tahrik ettiği (induce) anlamları ve davranışları; gerçek aktörlerin yerini alarak değil, davranışlarının bir yorumunu onlara sunarak inceleyecektir. ${ }^{30}$

Metinde "to induce" kullanılmakta. Çevirisi -en hafifinden başlayarak"ikna etme, teşvik etme, sevk etme, neden olma, tahrik etme ve kandırıp yaptırma"ya kadar gider. Başka yerde de "seduction" kullanıldığına bakılınca, bütün tahrik veya kışkırtmalar yöntem gereği; "müdahaleci yöntem" gereği yapılmaktadır.

Bu nedenle, N. Göle "intervention" terimini "müdahale" sözcügüüle çevirmenin yanlış çağrışımlar yapabileceğini söylerken hatalıdır. Ya da şöyle diyelim: yanlış dediği çağrışım hiç de yanlış değildir. Touraine o terimi gayet bilinçli kullanmaktadır ve gerçek bir "müdahale"dir yönteminin yaptı$\breve{g}_{1}$. Sosyolog ancak müdahaleyle, aktörleri eylemlerinin en yüksek olasılıklı ve olanaklı anlamını "keşfetmeye" ayıltabilir (bring to). ${ }^{31}$ Çalışmamızı "Touraine ve Göle karşılaştırması"na büründürme niyetinde değiliz. Bununla birlikte, yönteme adını veren "müdahale" teriminin iyi anlaşılması için buna biraz girişmek zorundayız. Türkçe'ye çevirirken, "müdahaleci sosyolojik yöntem" yerine "aktif katılmacı (gözlem değil) yöntem" demenin daha münasip olduğunu ileri süren Göle, gerekçesi olarak da, "çünkü müdahale sözcüğü çok fazla yönlendirme çağrıştırmaktadır" diyor. Peşinden gelen,

sonra gelen cümle bunun açıklaması olmalıdır. Halbuki, ikinci cümle "aktif bir sosyolog" tanımı yapmakta ve gramatik açıdan çok güçlü bir yapı kullanmaktadır. İşaret ya yanlış konuldu ya da İngilizce yazı kurallarında bu kullanıșın yeri var ama biz bilmiyoruz.

29 Touraine, "A Method", s. 904.

30 Touraine, "A Method", s. 905.

31 Touraine, "A Method", s. 905. 
"amaçlanan, bilginin sosyolog ile toplumsal hareket arasında, analist ile aktörler arasındaki iletişim aracılı̆̆ıyla üretilmesidir" cümlesiyle de gerekçeyi gerekçelendiriyor. "Amaçlanan" kelimesiyle başlayan cümle Touraine'ye gönderme yapıyorsa, ki öyle anlaşıllyor, gerekçeyi gerekçelendirmede kâfi değil. Touraine'den tarafımızca yapılan alıntıları da zihinde tutup biz de diyebiliriz ki, "hayır, Touraine tam da yönlendirme yapılmasını kastetmektedir."

Göle'nin şu cümlesine de dikkat çekelim: "Alan Touraine'nin sosyoloğa hipotezleri test etme ya da toplumsal hareketin kapasitesini artırma gibi daha 'volontarist' görevler yüklemesi karşısında, ben daha çok 'analitik mesafe' diye isimlendirebileceğim tavrı benimsemekteyim." ${ }^{2} 2$ İmdi, madem ki veya eğer Touraine sosyoloğa öyle bir vazife yüklüyor(sa), bunu yerine getirmek bir tür yönlendirme ile olur. Öyle sanıyoruz ki, buradaki sıkıntı cümlenin "volontarist" sözcügüüü de kapsayan sonraki kısmını anlamakla çözülebilir. Bu kez başka sıkıntı kendini göstermekte. Göle araştırmalarını hermeneutik (derin yorumsama) çerçevesinde yaptığına göre, bu geleneğin "insan doğası" varsayımının "voluntarist" ("istemci, istençci") olduğunu bilmekliği lazım. Her nedense kendini ondan uzaklaştırıyor ve, böylece de, "intervention" terimini "müdahale" şeklinde tercümeden yüz çeviriyor. Halbuki, onu "aktif katılma" kelimeleriyle çevirirken, "Ben Touraine ile biraz farklılaştığımdan yöntemi biraz değiştiriyorum, bunun için o terim bende başka bir hal alıyor" deseydi daha doğru düşerdi. Diğer yandan, Göle "analitik mesafe" tabirini hermeneutikteki "anlama mesafesi" mânasında istimal ettiyse, bu mesafeyi Touraine de koymakta. Özetle; Touraine'ye sadık kalacaksak, "intervention" terimini "müdahale" diye çevirmek adeta zorunludur.

İkna, teşvik, sevk, tahrik ve kışkırtma gibi edimleri kullanan böyle bir "yöntemsel müdahale" süreci, konu-öznelerin araştırmanın parçası olmaktan vazgeçmelerine yol açabilir. Bu nadirdir ve aktörler bu tür tahriklere (seduction) zamanla iyimserlik veya hoşgörü ile yaklaşabilirler. Kaldı ki, sosyoloğun incelediği aktörlere oranla daha bilinçli olmaklığı gerektiğinden, müdahale usullerini kullanırken "vazgeçme"nin önüne geçebilir; örneğin, "elde-hazır" olanlar yerine yeni doküman ve ortamlar yaratabilir. ${ }^{33}$ Her ne ise, ister sosyo-psikolojik ister sosyolojik yönelimli olsun, "sosyolojik müdahale"nin tanımı budur diyor Touraine. Sosyo-psikolojik olabilir; çünkü, bireylerin veya grubun "zihinsel, iç deneyimleri"ne ("inner life") odaklanır. Tamamen sosyolojiktir de; çünkü, toplumsal davranışlarını yön-

32 Nilüfer Göle, Modern Mahrem: Medeniyet ve Örtünme, İstanbul: Metis, 1991, s. 82, 7.dn. 33 Touraine, "A Method", s. 905. 
lendirecek bazı taleplerde ve hak iddialarında bulunarak, kurumsallaşmış normları bir şekilde sorgulayan toplumsal aktörleri ortaya çıkarır ve bize takdim eder. ${ }^{34}$

Öyleyse "müdahale" ("intervention") yalın "mülakat"1n ("interviews") ${ }^{35}$ ötesine gidecek ve daha uzun sürecektir. Bunun nedenini, terimlerin anlamlarını yorumlayarak da bulabiliriz. "İntervention" "inter" ve "to vent" bileşimi ise, kelime oyunu da yapılıyor. "To vent"in anlamlarından bazıları "dışarı salıverme, ifade etme; gösterme, belirmek..."tir. "To give vent to" yapısıyla kullanılınca "açı̆̆a vur(dur)mak" anlamına gelir. "İnter"in "karş1lıklılık" anlamı ise açıktır. Bu durumda "intervention" "karşılıklı dışarı salıvermeler", "karş1lklı ifade/tezahür etmeler", "karşılıklı gösterme ve belirmeler" ve "karşılıklı açı̆̆a vurmalar" anlamlarına gelir ki; "aktif katılmacı yöntem" tabirini tercih ederken Göle'nin zihnindeki bu idiyse haklıdır. Bunlar hem "aktörler ve sosyolog arasında", hem "aktörler arasında" yapılır ve yaptırılır ki her ikisi de toplumsal eylemi anlamaya yardımcıdır. Bunun da hayli uzun sürebileceği aşikardır.

"İnterviews" "karşılıklı görüş alışverişi" anlamına gelir aslında. Ne var ki der gibidir Touraine, hiç de böyle yürütülmemekte. Onu asıl anlamında uygulamıyorsak ve "müdahaleci yöntem"in "görüşler toplama" ameliyesi olmadığını biliyorsak -ki olmadığını bizzat ifade eder Touraine- yetersiz kalacaktır o ve müdahale onun ötesine gidecektir. Çünkü onunla yapılagelen "görüş alış"tır; "alış" ve "veriş" değil. Yani "aktif katılım" pek de söz konusu olmamakta. Hele bunun karşıllklı konuşmayla değil de, bazen sokakta rastlanılan kişilere "fikir/görüş sormak"la uygulandığını biliyorsak bu tespit daha da doğrudur. Bir 'teknik' olarak bundan da vazgeçilmese bile, aralarında çok fark var o halde. Zira "müdahale yöntemi", son derece uzun da tutulsa salt mülakattan öteye giderek bir toplumsal durumu yeniden oluşturur (recreates). ${ }^{36}$ Bunun için, grup yalnızca birtakım sorularla yüz yüze getirilmekle bırakılmayıp; gruba ilişkin olumlu ya da olumsuz tavır takınan gerçek bireylerle de karşıllklı ilişkiye ve etkilenmeye zorlanmalıdır. Sosyoloğun "gözetimi" altında grubun fiili deneyimini (yapıp etmelerini ve anlamlandırmalarını) yeniden inşadan sonradır; grup içlerinden birisinin yardımıyla kendinin bir yorumuna girişir. Bu yorum da diğer sosyologları bir hipotez kurmaya götürür. Hipotez guruba sunulduğunda; ancak grubun yeni duruma reaksiyon fırsatı bulduğu belli bir zaman diliminden sonra anlamı ortaya çıkmaya başlayan önemli ve anlamlı reaksi- 
yonlar gelmeye başlar. Peşinden, "müdahale"nin grubun toplumsal durumu anlama yeteneklerini artırdığı mı yoksa azalttığı mı gözlemlenmeli$\operatorname{dir}^{37}$

Kendi araştırmamızda grup bazı sorularla yüzyüze getirilmiştir. Fakat Touraine'nin telkininden fazlacaydı. Bu hem aktörlerle konuşmak maksadıyla oluşturulan veya kendiliğinden oluşan ortamlarda yapılmıştı, hem de onlara yazılı metin hazırlatılmasinda. "Grup" terimi ile yalnızca "insan grubu"nu değil de "düşünce grubu"nu da kastedersek; aktörler özellikle ikinci anlamda 'grup' ile irtibata ve etkileşime sokulmuş hatta zorlanmıştır. Touraine'nin demek istedikleri arasında bu var mıdı pek çıkaramadıksa da, grup veya düşünceler grubu başka insanlarla da bağlantıya sokulmuş ve olumlu ya da olumsuz değerlendirmeler göz önünde tutulmuştur.

Sonraki süreç özetle şöyledir. Sosyolog olarak denetimimiz altında, grubun fiilen söyledikleri yeniden inşa edilmiş ve arasıra bir kişiye izin verilerek grubun düşüncelerinin yorumunun yapılmasına götürülmüştür. Yazılı sorularla sınamayı düşündüğümüzden yorum birden fazla insana yaptırılmıştır. Başka söyleyişle; Touraine gibi tek kişi yardımıyla grubun kendi yorumunu yapmasını sağlamak yerine, çok sayıda kişiye, gruplarının fiilen dışında ama fikirler bakımından içeride düşünülen kişilerin ve düşüncelerinin yorumu yaptırılmıştır. Biraz evvel dediğimiz gibi, maksat "genelleme" olmayıp, onları benzer ya da farklı fikirlerle karşı karşıya getirip kendi yorumlarını önce zayıflatmak, sonra, mümkünse, güçlendirmekti. İşte bu yorum bizi bir hipotez inşaına vardırmıştı. Touraine'nin sözünü ediyor gözüktüğü, "diğer sosyologları bir hipotez kurmaya götürme" bizde vuku bulmamıştı. O böyle çalışmaların bilim insanları grubunca yapılmasını salık veriyor. Aklımıza bile gelmedi bizim. Fakat, "başka sosyologların da hipotez kurma" kapısı açık bırakılmıştır. Bizimki de öyle sınanacaktır. Kurduğumuz hipotezi farklı kelimelerle tekrar edersek; "insanların din algıları geleneğe ve birbirlerine göre farklı düşse bile, onların dinselliğinden şüphe etmeyebilecekleri" idi.

Bu hipotez guruba sunulduğunda, ancak grubun yeni durum tanımına reaksiyon şansı bulduğu belli zaman diliminden sonra anlamı ortaya çıkmaya başlayan reaksiyonlar gelmeye başlamıştır. Bu süreçte muhtelif "geleneksel" ve "yeni" fikirlerle karşı karşıya getirildiler. Böyle müdahalelerin, bireylerin adı geçen durumu veya sorunu anlama kabiliyetlerini artırdığ mı yoksa azalttığı mı gözlenmiştir. "Kabiliyeti artırma" ile Touraine de aynısını mı kastediyordu emin değiliz; kasıt "durumun veya sorunun şahsı-

37 Touraine, "A Method", s. 907. 
mızda ama bilimsel oluşan anlamına onları uyarmak ve uyandırmak" ise, bu yetenekleri umduğumuzdan fazla artırılmıştır. Misal; lafzen alınırsa bazı ayetler, hadisler ve din bilginlerinin söylediklerinin insanları ontolojik ay1rıma tabi tuttuğu konusunda sosyolog olarak zihnimizde kuşku yoktu, bunun Tanrı emri olmadığında da şüphemiz bulunmuyordu; yaptığımız "onaylayıcı" ve "onay bozucu" müdahaleler iki hususta da aktörlerin "anlama yeteneklerini" yükseltmiştir.

Touraine; uzun, meşakkatli ve karmaşık gözüken bu yöntemle yürütülen araştırmaların hemfikir olduğumuz şu önermeyi verdiğini söyler: Bir sosyolojik araştırmanın veya yorumun doğruluğu (accuracy), en iyi, aktörlerin bilinçlerini (farkındalıklarını) (awareness) ve eylem yeteneklerini artırma kabiliyeti ile test edilir. Çünkü "aktör" teriminin tam tanımı, kuralların ve normların sade ve sadece uygulanmasina veya bunlara atfa indirgenemeyecek olan, davranışları inşa ve meşrulaştırma (justify) yeteneğidir. "Aktör" bunları yerine getirebilendir ve getirebilmektir. Araştırma bilinçleri yükseltmiş ve bu yeteneklerini artırmışsa ve, sonra, bunları haiz aktörleri incelemişse işini yapmıştır. Elbette, kültür tarihçisi veya tarihsel antropolog, belli bir zamanda kurulmuş hipotezi başka zaman dilimlerine tatbik ederek doğrulamada zaman boyutunu kullanabilme bakımından daha iyi bir imkana sahiptir. Bakış açısı bu denli geniş değilse de, sosyolog da, aktörlerin mukabelelerine veya tepkilerine göre hipotezlerini değiştirebilme avantajına sahiptir. ${ }^{38}$

Aktör-odaklı sosyolojiye özgü bu yöntem alışılandan (conventional) hayli uzaktır. Bununla yapılan çözümleme ilerledikçe; evvelce "nesnel, birey dışı, sosyal" addedilen durum dağılır (shattered), artık niyetsel/yönelimsel (intentional) durum haline gelir. "Objektif", başka deyişle "dışarıda", "orada-var-kabul-edilen" veya "işte-oradaki" realite mümkün sonuçlardan yalnızca biri olur. ${ }^{39}$

$\mathrm{Bu}$ yöntemin kendi yöntemimiz ve araştırmamı ile en sıkı irtibatı bu noktadadır. Touraine, tırnak içinde yazdığ 1 "objektif"in açılımı olarak ilave ettiğimiz ve onu yansıttığından şüphe duymadığımız ifadelerle şunu söylüyor: Bireylere gerek başka insanlarca veya metinlerce, gerekse sosyal bilimcilerce yüklenilen "objektif, dışsal" "gerçeklik" veya "durum tanımı" ya tamamen darmadağınlaşır, ya da durum tanımlarından yalnızca teki olur sosyolojik çözümleme ilerlediğinde. "Nesnel durum"un kabullenildiği bile bu tür bir anlama vetiresiyle bulunabilir: Bireylerin algıları, "sorgusuz kabullenilen, olgusal durum"la örtüşebilir neticede, fakat evvela böyle olup

38 Touraine, "A Method", s. 906.

39 Touraine, "A Method", s. 906-908. 
olmadığını anlama sürecine girilmelidir.

"Dağılma" ya da "yerinde kalma" araştırmamızdan hareketle şöyle örneklendirilebilir: Çok eşlilik genelde onaylanan ve Kur'an tarafından da izin verildiği düşünülen bir "gerçeklik" veya "durum tanımı" olabilirse de; bazı bireylerde darmadağın edildiğini de bulabiliriz. Onun başka bazı bireylerde aynen kaldığı da anlaşılabilir. O halde yapılması gereken, muhtelif müdahalelerle, "özneye ulaşmak"tır.

"Özneye ulaşmak", norm ve kuralların geleneksel tatbikatıyla sınırlı olmayışı ölçüsünde, her eylem biçiminde bir "sosyal olmayan ilke"ye başvurulduğunu ve başvurmayı ihsas ve telkin eder. Touraine'nin "sosyal olmayan ilke" ile kastı, öznelerin düşüncelerini ve eylemlerini dayandırdıkları, yaygınlıkla paylaşılan veya paylaşıldığı düşünülen bazı normlardan ayrı hatta, bazen, tamamen ters bir takım bireysel anlamlandırma ilkeleridir. Onun mevcudiyetini en azından varsayarak, sosyolog, örneğin ekonomik determinizmden yüz çevirmeli, ekonomik analiz gibi "rasyonel tercihe" atıfta bulunmamalıdır. Böyle bir 'rasyonalizmi' kenarda bıraktığımızda, toplumsal eylemin çoğu biçimi, genel kamu yararı ve halkın egemenliği fikirlerine indirgenemez bir "eşitlik ilkesini" dışavurur. ${ }^{40}$

Bunu din sosyolojisine taşıyınca, dindar bireyin düşünce veya eylemini, dinsel eylemin genel onaylı tanımlarını kabul etme ya da etmemeyle sınırlandıramayız. O, sanıldığının aksine, ne "Tanrının var sayılan mutlak emri", ne de "toplumun birlik ve dirlik (kamu yararı)" ilkesi açısından düşünüyor ve davranıyordur. Dinsel arzu, istek, talep, iddia ve duygular kamu yararına irca edilemezler, indirgenemezler diyen Touraine de bir çok sosyologun bu hataya düştügünü hatırlatır. Öte taraftan, din toplumsal alanın muayyen bir kutsallaştırılışını gösteriyorsa; herhangi bir toplumsal gücü sınırlandıran veya onunla mücadele imkanı veren bir "ilahî güc"e veya "aşkın kudret veya ilke"ye de gönderme yapılır. ${ }^{41}$ Yanlış okumadiysak; bu temel ilkelerden en önemlisinin "eşitlik" olduğunu, temel ilke zannedilen "adalet"in onun somutlaşımından ibaretliğini söylemesi anlamlıdır. ${ }^{42}$ Aktörlerimizin metinlerinde belki de en fazla dikkat çeken husus tam da buydu.

Özne (the Subject) Aramak

Fakat, diyor -bu "fakat"a biz de katıllyoruz- sosyolojinin kendi böyle bir "aşkın ilke"ye doğrudan dayanamaz, müracaat edemez. Onu, diyelim, Tanrı'-

40 Touraine, "A Method", s. 908.

41 Touraine, "A Method", s. 908.

42 Touraine, "A Method", s. 908. 
nın veya bir mükemmel toplumun varlığını çözümleme temeli olarak alamaz. Böyle bir "teolojik perspektif"ten kaçınmanın biricik yolu; toplumda yerleşik geleneksel kurallara her türlü direnmeyi, toplumsal çevresinin aynı zamanda yaratıcısı olan "kendini oluşturan insan"ın ("self-created human being”) benlik arayışı olarak yorumlamaktan geçer. O, bu gibi haklar adına; özgürlük için çekişmelere, çatışmalara, uzlaşma arayışlarına ve mücadeleye girişen birisidir. Toplumun içerisinde ve içerisinden nihai belirleyici bir "iyi ve kötü ilkesi" bulmaktan çok uzakta, diyor Touraine, "benim Özne (the Subject) dediğimden veya, başka bir söyleyişle, özgür aktörler olma hakkı için bireysel ve kolektif taleplerden bahsediyoruz. Buradan anlaşllıyor ki, "Özne" ("the Subject") bir "talep", bir "reddiye", bir "özgürlük"; toplumca belirlenmiş statülere ve sosyal rollere karşı "Özne"nin yaratıcı özgürlüğüne dolaysız ve dolaylı bir çağrıdır. Bundan ötürü, sosyolojik müdahalenin gayesi, olumsuzlamaların ve reddiyelerin tam göbeğindeki sslahat (reform) taleplerini gözler önüne sermektir. Zira, en 1lımlı aktör bile, toplumsal/geleneksel düzeni dayatan ve meşrulaştıran normlara aykırı düşen bir "ahlak ilkesi"ne; başka söyleyişle, taviz verilemez bir ilkeye baş vurmaktadır. ${ }^{43}$

Kendi çalışmamızda varılanı özetleyebilecek bir tespit de yukarıdaki belirlemeleridir Touraine'nin. Yani, sosyolog olarak kendimiz müracaat etmediysek de, aktörlerimiz, yine Tanrı'ya atıfla, ama değil kendilerinin Tanrı'nın bile vazgeçemeyeceğini düşündükleri bir ilkeye müracaat etmekteydiler. Bu “eşitlik ilkesi”nin Kur'an'da lafzen çok açıkça yer alıp almadığı veya geleneğin onu hesaba katıp katmadığı önemli hususlardan değildir. Belki şu bile söylenebilir; onlar bizzat Tanrı'yı "Eşitlik" algılamaktaydılar.

Touraine fenomenolojiden ve fenemonolojik sosyolojiden bahsetmez. Ama "the Subject"i hem "kişi" hem "bilinç halleri" anlaması; "bilinci" ve "bireyi" gerçek özgürlük addeden fenomenolojik eğilime uygun düşmekte. Burada "birey" bir yanıyla toplumdadır. Diğer yanıyla, topluma 'batmayan' bir "varoluş" ifade eder; o, "birey" kavramının anlamı gereği bir "özgürlük talebi", bir "hürriyetsizlik reddiyesi" ve "bizatihi özgürlük"tür. "Birey" veya "the Subject" iki yanıyla da "kimlik"tir. O, tekrarlarsak, toplumsal olarak belirlenmiş konumlara ve durum tanımlarına karşı, yaratıcı özgürlüğe dolaylı ve dolaysız bir çağrıdır. ${ }^{44}$

"Sosyolojik müdahale" hakkında söylenenler araştırma konusu ile ilişkisindeki farklılığı ihsas eder. Diğer çoğu yöntem incelenenin "bilincini" hesaba katma gereği duymaz; ya bilinç mevcut olmadı̆̆ından ya da yapı-

43 Touraine, "A Method”, s. 909-910. Bunların Kant ile ilişkisi şu an konumuz dışındadır. 44 Fenomenoloji damarı inkar edilemeyecek Sartre ile karşılaştırmakla da anlatabilirdik bunu. 
salcı linguistikçiler veya yapısalcı antropologlar gibi "doğa bilimlerine öykünen insan bilimleri" ("natural sciences of man") ile ilgilendiklerinden. ${ }^{45}$ Halbuki, sosyoloji öznelliği (bilinci, bilinç yönelimini, subjectivity) hesaba katmadan edemez. Belki yalnızca, bireyi veya bir grubu "aktör" yapan temel niteliğe ulaşmak üzere öznelliğin içine yeterince derinden girerek veya onu yeterince derinden deşerek (delving) öznellikten (subjectivity) zorunlu bir uzaklık da elde eder. ${ }^{46}$ "Öznellik" öznenin zihnine girip onun ilk bakışta görünen tezahürlerini askıya almaktır da. "Anlamacı" veya "derin yorumsamacı gelenek" açısından bakılırsa denilen şudur: "Konularımızı" "özneler", davranışlarını ve ürünlerini de "öznenin nesnelleşmiş, dışavurmuş anlamları" alarak, gerçek anlamlandırmalarına ulaşmak üzere, "yönelimsel bilince" gideriz veya gireriz. Özne-konuların subjektivitesine girmekle ancak, nesnelleştirmelerini (objektifleştirmelerini) anlayabiliriz. Bazı fenomenoloji türlerindeki gibi, bu süreçte "başkasının öznelliğinde kaybolma tehlikesi" de var. Bunun için araya "anlama mesafesi" koymalıyı. Ama, "anlama mesafesi" bilince daha derin yerleşerek de kazanılabilir. "Konunun öznelliğine" derin dahillikle onun "öznelciliğinden" kurtuluruz; çünkü insanların yüzeyde gösterdikleri anlamlar mekanik ve durumsal tezahürler olabilir. Tezahürleri deşerek, onlardan sıyrılırız. Yani, bir bakıma, özneyi kendisinden daha iyi anlarız.

Öyleyse bu bir "ontolojik birleşme" olmayıp, böyle özdeşleşme mümkün de değil. Gördüğümüz üzere, Touraine, "davranışları gerçekten aktörlerin yerini alarak değil; kendi davranışlarının yorumunu onlara sunarak incelemeliyiz" demekteydi. Bu ifadesiyle, ontolojik birleşimi kabul etmediği bir yana; sadece yüz yüze çalışmada takınılacak bir yöntemsel tutum olduğunu söylediğini de düşünmeyebiliriz. Zira bu metin yorumlarında da kullanılan bir ilkedir. "Onları kendi davranışlarının bir yorumunu sunarak incelemeliyiz" teklifinin metin analizinde sıkıntı doğurabileceği, "karşımızda kişiler bulunduğunu" ihsas ettiği, bununsa doğru olmadığı düşünülebilir. Fakat biz gördük ki metinler de böyle incelenir. Onlar karşılıklı konuştuğumuz canlı varlıklardır haddi zatında. Bazı ön fikirlerle yaklaşır, bir ön anlamayla yanaşır ve bazı sorular sorup cevaplarını isteriz metinden. Zira o bir bilinç ürünüdür ve öznedir ve başka bilinç (araştırmacı, anlayan özne) ile karşı karşıyadır. Aldığımız cevaplarla hem önceki varsayımları değiştirebilir hem yenilerini kurarız. Böylece, metnin fiziksel olarak karşımızda bulunmayan yazarına "yazdıklarının bir yorumunu sunarak" inceleme yapmış

45 Touraine, "A Method", s. 910.

46 Touraine, "A Method", s. 910-911. 
oluruz. Özne-konunun ya da özne-yazarın ille de fiziksel varlığıyla karşımızda durması icab etmez karşılıklı konuşabilmek ve yorumlarımızı ona sunmak için. "Özne" fiilen karşıda olsun olmasın tek yapılacak, onun öznelciliğinde takılı kalmayıp onu da aşan derin öznel anlamlara ulaşmak üzere özneyi "deşmek"tir.

Önceki çalışmalarımızi ${ }^{47}$ okuyanlar, bilhassa "öznellik" ve "nesnellik" tartışmalarının geçtiği yerlerde kullandığımız terimlerin biraz kafa karıştırıcı olduğunu hatırlayacaklar. Yukarıdaki gibi oralarda da "öznelcilik"in aslında "nesnellik tavrı" olduğunu ileri sürmüştük. Biz ve istifade ettiğimiz sosyal bilimciler kelime oyunu mu yapıyor, sözlük zorlamasında mı bulunuyorduk?

Touraine'ye de böyle eleştiriler yöneltilmiş veya yönelebileceğini düşünmüş olmalı; bunun da dolaylı yanıtını verir: Öznelleştirmeyi (subjectivation); yani, çevrelerine kendi beklentilerini, amaçlarını, ülkülerini göstermeye çalışan "bir(er) aktör olarak" bireyin yahut grubun kendini-sunmasını veya kendilik-imgesini (self-representation) keşfetmek için "öznelliğinin" ("subjectivity") ötesine geçmeyi salık verirken lügatçemizin (vocabulary) sınırlarını zorluyor değiliz. ${ }^{48}$ Anlamanın konusunun; yani aktörün/ aktörlerin "öznelleştirmelerini" bulmak maksadıyla "onların öznelliğinin" derin tabakalarına girmenin gerekliliğini dile getiriyoruz, ve bu bir çelişki değildir.

Bunu anlamacı paradigmanın genel diliyle söylersek: Aktörün zihnine ne kadar derinden girersek, onu ne kadar derin "deşersek", "benlik-imgesine" o kadar yakınlaşırız ve, bu da, onun kendi asıl benlik imgesine dahi taalluk etmeyen öznel/keyfî anlamlandırmalarını askıya alma imkanı verir. Daha $\mathrm{m} ı$ açık olsun: İnsanlar ilk anda pek fazla düşünmeden konuşur ve davranırlar; bunları hemen "içsel maksat"ın tam göstergesi almak yanlıştır; aktörün kendisi bile bilmekte ki onlar yüzeyde gösterdiği eylemlerdir ve, tabiri caizse, "ilk anda aklına estiği gibi" yapmıştır belki. Bilimsel araştırma, bu "görünen ve görülen"in "resmini çekmek" olamaz. "Ben-bir-kamerayım" tutumuyla inceleme yaparak ancak "nesnel" olunabileceği düşünülüyorsa, bu bilimsel açıdan da kusurludur, zira bizzat öznen bizi yanıltmaktadır. Nesnellik demek konumuzun öznelliğini hiç hesaba katmamak değil, öznelliğine daha derinlemesine yerleşerek onun ilk bakıştaki tezahürlerini aşmaktır, belki fenomenolojik askıya almaktır. "Niceliksel" araştır-

47 Adil Çiftçi, Nasıl Bir Sosyal Bilim: Temel Sorunlar ve Yaklaşımlar, Ankara: Kitabiyat, 2003. Ve, Anlayıcı Yaklaşım.

48 Touraine, "A Method", s. 911. 
maların kullandığı resim çekici ve sayı bildirici teknikler de bu açıdan kusurludur bu yaklaşıma göre. Zira onlar da öznelerin ilk anda gösterdikleri eylemleri veya verdikleri cevapları bilgi hatta "nesnel bilgi" addederler. Halbuki, "müdahaleci yöntem" tarafından bakılınca, bu ne nesnel bir yöntemdir, ne de bulunan nesnel bilgidir. Olsa olsa "nesne bilgi"; başka deyişle "nesne izlenimi"dir.

\section{Anlama ve Yorumun Geçerliliği}

Peki ama, diye sorar Touraine, yöntemimizi benimseyen ve uygulayan sosyoloğun yorumunun geçerliliği; "geçerlilik" bir bakıma "nesnel geçerlik" olacağından, "nesnelliği” için hangi kanıtı var ve "öznelliğine" yani kendi görüşlerine ve inançlarına karşı bizzat kendisini nasıl korumaya alacaktır? Bunun bir yolu diye, o, bir toplumsal aktör veya hareket araştırmasında aynı veya benzer grupları, metinleri veya dokümanları inceleyen araştırma ekiplerinin bulunmasını -ki biz bunu yapamadık- gösterir. Böyle bir çalışma, ana hipotezin, başlangıcından itibaren ortaya çıkan durumlara mukabelelerce reddedildiği ya da geçerli kılındığı ilkesine dayalı olacağından; aktörlere uygulanan hipotezlerin hatalılığı veya yeniden-düzenlenme gereği ortaya çıkabilir ve çıkmıştır. Çıkmayabilir de. İkisini de "ekip" ortaya koyabilir. Bu yanıtın yetersizliğini bildiğinden tekrar sorar: Araştırmacı diğer araştırmacıları ve aktörleri aldatan veya yanıltan bir yorumlar düzeneği inşa etmediğinden ("uydurmadığından" mı demek isterdi?) nasıl emin olabilir? Her araştırma ekibinin kendini eleştirel değerlendirmesine ilaveten; soruya verilebilecek tek muhtemel cevap, sosyal aktörün hiçbir zaman tek başına veya kendi iddiaları, kendi tezahürleri hatta kendi uygulamalarıyla değil; ayrı veya benzer ama incelenmekte olunan eylem alanında muayyen bir ilişki ile onunla irtibatlı diğer aktörlerle münasebetleri vasıtasıyla tanımlanması (anlaşılması) gerektiğidir. ${ }^{49}$

Böylece "sosyolojik müdahale"nin başka merhalesine geçilir: Aktör'ün kendini "aktör sıfatıyla" yapılandırdığı veya sergileyip öne çıkardığı ortam ve sosyal ilişkiler, çatışmalar, çekişmeler, uzlaşmalar ve tavizler örüntüsünü inşa etmek. Burada da tek hedef (the aim), aktörü aktör niteliğiyle keşfetme veya açığa çıkarma; başka deyişle, "toplumun üretiminde" bir aktif katılımcı görmektir. ${ }^{50} \mathrm{Bu}$, en dolaysız biçimde, siyasal kararları ve kamusal yahut kişisel politikaları şekillendiren süreçler incelenirken yerine getirilmektedir. İşte, bahsedilen ve benzeri süreçlerin ve ne anlama geldiğinin

49 Touraine, “A Method", s. 911.

50 Touraine, "A Method", s. 911. 
yeniden-inşası, söz konusu eylemin anlamı ile ilgili hipotezleri geçerli kılmanın en uygun yollarındandır. ${ }^{51}$ Belki ancak bu yoldandır ki, araştırmacı, anlamların nesnel olarak neye karşılık geldiğini de bulabilecektir. Fakat bu "mütekabiliyet" dışarıdan yüklenilen değil, özne tarafından yüklenilen bir mütekabiliyet olacaktır..

Touraine, doğrudan kullanmıyor gibiyse de, "anlamacı yaklaşım"ın, özellikle fenomenolojik sosyoloji kolunun kavramsal çerçevesine yanaşmakla kalmayıp iyice dahil hale gelmiştir artık. "Açıklamacı yaklaşım”ların aksine, eylemlerin kendilerine değil de eyleyenin yönelimsellikler(in)e vurgu yapan bu tutum eylemleri (actions) zihinsel edimlerin (acts) dişavurumu gördüğünden, onları anlamanın eyleme yönelen bilince bizim yönelmemizle mümkünlüğünü kabul eder. Bunu yapabilmek için karşımızda eylemin bulunması gerekse de, çıplak eylem kendi anlamını kendi veremez çünkü. Kimbilir şöyle anlatmak daha uygundur. O, biraz evvel geçen "intentional actions" tabirini bilinçli istihdam ettiyse, neredeyse tam göbeğinde yer almakta Fenomenolojinin. Zira, ona yeterince aşina birisine, "merkezi kavramı nedir?" diye sorulsa, cevabı kesinlikle "intentionality" olacaktır. Touraine bu terimle hermeneutik yönelimli toplumsal bilimlerin umumi öncüllerinden birini de tebarüz ettiriyor: En yerleşik, en az şüphe duyduğumuz, en sorgusuz sualsiz kabul ettiğimiz inançlar, kurallar, davranış biçimleri; kısacası, "toplumsal dünya" birilerinin zihinsel/yönelimsel edimleriyle inşa edilmiş ve başka zihinsel/yönelimsel edimlerle sürdürülen bir dünyadır. Onun kurumsallaşmışlık yani bir nevi "nesnel/olgusal gerçeklik" halinde durması, yönelimsel bilinçle kurulmuşluğunun üstünü örtemez. Kaldı ki; "kurucu bilince" gitmeden "kurum haline gelen"in anlamı bulunamaz. Touraine'nin fenomenolog olduğunu kanıtlama peşinde değilsek de; önerdiği türden yöntemle bir araştırmaya girişen sosyoloğun öncelikle pozitivistlerin tanımladıkları mânada "sosyal organizasyon" veya "toplumsal düzen" kavramlarını reddedeceğini; toplumsal dünyanın, asla düzen içerisinde işgal ettikleri yere göre belirlenemeyecek ve tanımlanamayacak olan aktörler arasındaki determine edilemeyen yönelimsel ilişkilerle sürekli kurulan ve yıkılan bir dünya olduğunu kabul edeceğini bizzat söylemesi ${ }^{52}$ bize güçlü bir destek sunmaktadır.

"Subject'e, Özne"ye "niyetsel, yönelimsel eylemleri" ("intentional actions") vasıtasıyla ulaşma ve onların ötesine/ardına varma gayretini takiben; organize etkinlikleri, kurumları ve hatta "metinler"i incelemeye de

51 Touraine, "A Method", s. 912.

52 Touraine, "A Method", s. 913. 
geçilebilir. Burada, kültür tarihçisine veya tarihçiye çok benzer şekilde, en kurumsallaşmış gözüken değer yönelimlerinde bile, değerlerin ve kültürel yönelimlerin "kurumsallaştırıcısı" olan aktörlerin eylemlerinin ve sosyal ilişkilerinin "anlam belirtilerini" ("signs") ararız. ${ }^{53}$

Touraine'nin bu yöntemsel yaklaşıma "metinleri" (texts) de uygun görmesi bahsettiğimiz araştırmamız açısından ipuçları ile doludur. Metin ya da diğer toplumsal eylemler olsun bir şekilde "kurumlaşmış" görünen durumlar, yaratanların ve sonraki muhatapların zihin süreçlerine geri gönderilirse ancak, "anlama döngüsü" tamamlanabilir. Onun kuramıyla böyle bir bağlantı kurmamıza büyük harfle yazdığı "the Subject" kavramı da yardımcıdır. Çünkü, ona yalnızca "bireyliği" değil de; "itaat", "itaatsizlik", "özgürlük" gibi edimleri de atfettiğine göre, onu "Zihin" diye çevirmek pekala mümkün görünmekte.

O halde; sosyolojik anlam çözümlemesi müteakip iki hareketi ayırırsa gücünü yitirebilir: Sistemden aktöre veya, belki daha uygunu, Özne'ye doğru yukarı hareket ve, sonra, toplumsal hayatın organize hatta kurum(sal)laşmış biçimlerinin izahına doğru aşağı hareket. Öznelerin kurulu veya toplumsal normlardan uzaklaşması ve farklı normlar ortaya koyması arasında sürekli bir gidiş geliş mevcut olduğu için de elzemdir bu. "Hermeneutik döngü"nün anlamlarından birini çağrıştırıyor gözüken bu sözleri sonrası Touraine, "Toplumsal değişmeyi mümkün kılan da budur zaten." ${ }^{4}$ der.

Son cümle yanıltmamalı. O "sosyal değişme" fenomeninin kendiyle alakalı ise de, asıl götürdüğü onu nasıl anlayabileceğimizdir. Başka deyişle; "değişme" öznelerin yukarıda betimlenen ikili hareketiyle meydana gelirken; biz de toplumsal değişmeyi bu "ikili hareketle" anlayabiliriz. Bundan önce, onun ancak böyle farkına varabiliriz. Değişim fenomeni ile ilgisi şu tarzda kurulabilir. Belli kabuller ve uygulamalar düzeninde yaşayan aktör, sistemden kendisine bir geliş görür ve onda bir algı bırakır bu. Sonra, kendi zihinsel çerçevesinde ona tekrar anlam vererek bir gidiş hareketinde bulunur. Empirik algılanan toplumsal normlar ile, aktörün subjektivitesinin anlamlandırmalar1 ya uzlaşır ya da ayrılır. Birinci durumda ortak dünyaya katılım veya onu tasdik meydana gelir. İkinci durumda farklı normlar teklif edilmekle kalınmaz, onların aktörün kendisi için gerçekliği de benimsenir. "Toplumsal değişmeyi mümkün kılan da budur zaten" ifadesi de anlamını böyle bulur.

Meseleye araştırmacının "yöntemsel hareketleri" açısından bakarsak şöyledirler. Duyularımızın önünde kendini olgumsu gerçeklik olarak sun-

53 Touraine, "A Method", s. 912.

54 Touraine, "A Method", s. 912. (Vurgu bizim). 
makla bırakmayıp, bazı hatta çoğunluk insanlarca da onaylanan bir inanış ve davranış düzeni/sistemi vardır. Bu düzen belli ölçüde aktörlerin zeminini oluşturduğundan ama aktörlerden tamamen müstakil bulunmadığından; yani hem bir nevi "nesnel gerçeklik" hem de "öznel ürün/yaratı" olduğundan, yapılacak hareket düzenden zihne doğru, yukarıdır. Fakat zihin veya özne aynı zamanda onu sorguladığından, tekrar aşağı bir hareketle ondan düzene gelinir. Yani, "nasıl algılıyorsun" gibi sorular sorulur ve izahları alınır. Aktörün "verili" kavramsal ve uygulamasal dünyadan uzaklaşması ile yeni normlar üretmesini ancak böyle anlayabiliriz. Burada, o halde, o cümleyi şöyle değiştirmemiz gerekir: "Toplumsal değişmeyi anlamayı mümkün kulan da budur zaten."

Sosyolog hangi yollarla, toplumsal düzenin dışına çıkma ve değiştirilmiş formlarına geri gelme şeklindeki "ikili hareket"e eşlik edebilir hatta onu önceleyebilir? İlk yolun bizzat sosyoloğun kendisiyle ilgisi yoktur: O, toplumsal norm düzenindeki veya düzen ile özneler arasındaki ciddi sapmaları, boşlukları, çatışmaları ve akim/sonuçsuz kalmış uzlaşmaları ve benzerlerini yalnızca dikkatle gözlemeli, görmelidir. Peşinden sormalıdır: Bu nereye götürür gibidir? Toplumsal varoluşun hangi düzeyi veya unsuru reddedilmekte grup tarafından? Her aktörün birbirine nispetle konumunun, haklarının ve yükümlülüklerinin tanımı mı reddedilmektedir? Yoksa reddiye veya çatışma toplumun kültürel yönelimlerine/değerlerine ve temel iktidar ilişkilerine mi uzanmaktadır? ${ }^{55}$

Cevabın ortaya çıarılması için, grubun biraraya geldiği muhtelif hallerde veya grup üyelerinin arkadaşları ve yakınları ile görüş alışverişinde bulunurken duyduklarını ve eldeki dokümanlarını hesaba katarak; sosyolog müdahale etmeli ve eylemin en muhtemel düzeyi görünen düzeyi belirlenmeli ve tanımlanmalıdır. ${ }^{56}$

Şöyle de denilebilir; o muhtelif müdahalelerle aktörleri eylemlerinin en yüksek ihtimale sahip anlamlarına kışkırtmalı ve "ihtimali en yüksek anlam"1 çıkarmalıdır. Bu, bizim de, çalışmanın meydana gelebilmesi için gerekli konuşma, iletişim ve diğer yakınlaşmaları tesis girişimimizde; çalışmayı gerçekten anlamacı kılmada gerekli "anlam düzeylerini" yakalama teşebbüsümüzde defalarca kullanılmış ve özneler farklı anlam katmanlarının farkına vardırılmıştı. Bazı konuşmaların sınav sorusu şeklinde düzenlenmesi de buna, sanılacağının aksine, olanak sağladı. Zira sorular, aynı noktalarda birleşiyorlarsa da, öznelerin kendilerini nasıl daha iyi ifade ede- 
bilecekleri akılda tutularak farklı da soruldular. Böyle bir "müdahale" ile, ortama dahil ve müdahil olma ve en olasılıklı anlam düzeylerini yakala(t)ma amaçlanmıştır. Touraine, "sosyolojik müdahale"nin ilk anda belli belirsiz gibiyse de bir "toplumsal hareketin" mevcudiyetini sergilemeyi amaç edindiğini; diğer deyişle, "genel eğilimlere/değerlere" ve "iktidar ilişkileri sistemi"ne "muhalefetin" varlığını açığa çıkarmayı hedeflediğini de söyler ${ }^{57}$ ki, bir yere kadar bizim çalışmamız da böyle okunabilir.

Sosyolog şu ana kadar anlattığımız yollarla hipotezinin geçerliliğinden emin olunca grubu ona iknaa çalışmalıdır. Muvaffakiyetten hemen sonra, bizzat aktörlerin kendi eylemlerini yeniden-yorumlamaya ve örtülü anlam ve uzanımlarını teklif edilen açıdan çözümlemeye yetenekli olup olmadıklarını gözlemlemeli. Zira, hipotezin geçerliliği incelenen bireylerin düşünme ve eyleme ve "kendi eylemlerinin anlamın daha iyi anlama" kapasitelerini artırma gücüyle sınanır. ${ }^{58}$

Araştırmacının bunca faal ve etkin olduğu; özneleri iknaa ve böylece belli bir yoruma veya yorumlara tahrike (seduce) de çalıştı̆̆ böyle bir çalışmada, rolü grubun direnmesini güçlendirmek, şüphelerini ve eleştirilerini seslendirmelerine yardım etmek olan başka araştırmacının nezareti gerekebilir. ${ }^{59}$ Biz en doğru anlam ve eylem düzeyini ortaya koymak gayesiyle belli yorumlara öznelerin dikkatini çekerken ve güçlü bir ikna çabası içerisindeyken;'nezaretçi' de muhtelif müdahalelerde bulunarak bireyi veya grubu yorumlarımıza karşı uyanık tutar ve belki söylediklerimizin aksini söyletmeye kışkırtır.

\section{Sosyoloji, Sosyolog ve Değişim}

Touraine'nin, bu yöntemi veya yöntem teklifini sosyologları da değişim asrının üyeleri görerek gerekçelendirmesi dikkat çekici. Günümüzde sosyolojinin belki de ana konusu olan "sosyal değişme" fenomenini şahsen hayatlarında yaşadıkları halde, yöntemlerinde bunun emaresi görülmeyenlere, "kendinize gelin" uyarısında bulunmak niyetiyle şöyle der: "Sürekli değişen, teknolojik yeniliklerle, toplumsal çatışmalarla ve kültürel dönüşümlerle dopdolu bir toplumun üyelerinden (sosyologlardan) bunu beklemek hakikaten de aşırı bir beklenti midir?"60 Değişim, diyor Touraine, "vardır". Ve değişim; değerler, ümit, öfke, tahliller, stratejiler, durum tanımları ve

57 Touraine, "A Method", s. 912.

58 Touraine, "A Method", s. 913.

59 Touraine, "A Method", s. 914.

60 Touraine, "A Method", s. 913. 
durumları tanımlama istekleri ile harekete geçirilen faillerinden ayrı tutulamaz, sosyolog da tutamaz. Şöyle devam eder: Bu aktör-odaklı ve "değişim" merkezli sosyoloji, "inanıyorum ki, geleneksel sistem-odaklı sosyolojinin yerini almaktadır." 61

Herkesin aktörleri özgür ve yaratıcı varlık gören bir sosyolojiyi benimsemesi şart değil. Onun gittikçe yaygınlık kazandığı da söylenebilir; ve yeni çalışmalar 1şı̆̆ında sürekli gözden geçirilmelidir, geçirilmektedir. ${ }^{62}$ Yapılması gereken ilk işler ise aynı kalacaktır: Aktörlerin durum tanımlarına ve tanımlamalarına "belirlenimci" görüşle yaklaşmamak. Bundan dolayı, klasik açıklamalardan uzaklaşma ve uzaklaştığımı "hissi" en iyi araştırma rehberimizdir. "Determinist açılamalar"ın zorlamalarından kurtulmuş oluruz böylece. Bir eylemin veya davranışın son derece bariz bir "nedeni" tespit edilemiyorsa ve zaten yoksa; hemen inceleme altındaki eylemin "niteliğine" düşünce ve dikkatimizi yoğunlaştırmak zorunda kalırız. Diğer yandan; tarihi sürekli bir değişim süreci görmek de tek başına zayıf düşer; ve çok yüzeysel ve keyfî şekilde tanımlanan durum tarafindan veya durum tanımıyla kolayca belirlendiği düşünülen "sonuçlarını" keşfetmeye koyulmadan önce, eylemin "içsel, zihinsel niteliği"ni çözümleme mecburiyetinde kalırız. Böylece de; "Bir eylemin nedenleri ve sonuçları tarihsel olaylar tarafından ortaya çıkarılır" şeklindeki sureta (apparently) doğru ilkeden ayrılarak şu zıt ilkeye gideriz: "Olayların akışı ancak muhtelif türden eylemleri soyutlayarak ve birbirinden ayırarak anlaşılabilir." ${ }^{63}$ Buna yönelik olarak sosyolog bir failler (agents) düzeneğini ve paylaşılan kültürel kaynaklar içerisindeki ve hepsi bunların kullanımını etkilemeye çalışan aktörler arasındaki çatışma ve çatışmama ilişkilerini tahlil etmelidir. ${ }^{64}$

Sosyolojinin "toplumsal aktörlerin ve ilişkilerinin incelenmesi" şeklindeki özel tanımının kabul göreceğini iddia etmenin abartı olmadığını söyleyen Touraine; onun yöntemleri üzerine tartışmaya girerse özgün yer edinebileceğini ifade eder. Bu tartışma "kendini-kötüleme"65 veya "kendinitahrip" maksadıyla değil; ekonomik determinizm, iktidar gerekleri/dayatmaları (the logics of power) ve dinsel, siyasal ve sinif-merkezli kuramlar karmaşasında "bağımsız aktörler" arayışı olarak kendini tanımlama niyetiyle yapilacaktır. ${ }^{66}$

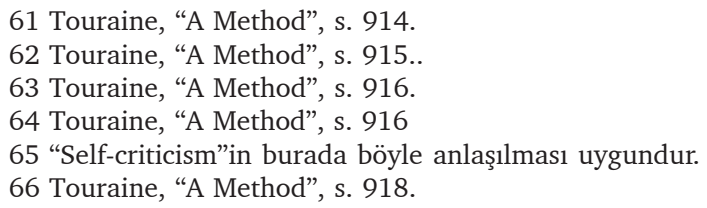




\begin{abstract}
"Kitap", Kitaplar ve Sosyolog
Yalnızca birkaç kez açıç̧a "metinler"den bahsedilmesine rağmen; "müdahaleci yöntem" onlar ile de ilgilidir. Bilhassa din sosyolojisi araştırmalarında en fazla bu konu tartışılmakta, "niceliksel" ile "niteliksel" arasındaki çelişme en çok bu meselede başgöstermekte günümüzde. Touraine şunun farkındadır: Batı'da bazı araştırmalar diyelim Marx'ın metinleri ile Marxist toplumsal hareketler hatta bireyler arasında doğrudan ilişki kurarak tam "mütekabiliyet" bulunduğunu kabul etmişler ve çıkarılan sonuçlar da epeyce zorlama olmuştur. Kendilerini bu metinlere dayandırmaları ayrı husustur; öyle olamasaydı hareketlerin ismi "Marxist" konulmazdı. Fakat, Touraine'nin toplumsal düzen ile aktörler arasında tam bir tekabuliyet yoktur tezini buraya uyarlarsak şöyle de diyebiliriz: Marxist kitabî düzen ile aktörler arasında birebir mütekabiliyet yoktur, olmayabilir. Bunu din sosyolojisine taşırsak, demek isterdi ki; araştırmaları "Kitap/Kur'an/Metin" ile "mümin aktörleri" eşleştirici tutumla yapmayınız. Diğer yandan eşleştirme, küçük harfle, "kitaplar" ile "aktörler" arasında da yapılmamalı; sözgelimi, herhangi bir dinsel hareketi anlamak "dayandıkları kitapları anlamak" olarak düşünülmemelidir. Eserlerinde bunu gerçekten kullandı mı bilmiyoruz, onu benimsediği anlaşılan sosyologlardan karine yoluyla çıkarıyoruz ama; Touraine'nin yaklaşımı, metinler ile muhatapları tüm müdahale yollarını istihdamla "karşı karşıya getirmek" isteyecektir. "Kitaplar" yerine "düzen" yazarsak; "kitap-düzen"den aktörlere doğru değil yalnızca, aktörlerden de "kitap-düzen"e doğru hareket edilip aradaki çelişkiler, uzlaşmalar ve çatışmalar görülenecek ve dışavurdurulacaktır.
\end{abstract}

\title{
Epistemoloji
}

$\mathrm{Bu}$ yaklaşım, anlamaya çalıştığımız insanları ilişkilendirdiğimiz "kitaplar"ın "araştıran özne"yi; anket ve benzerlerinin de "araştırılan özne"yi koşullandırdığını düşünecek göründüğüne göre, nasıl bir epistemoloji kendi yöntemlerinin gerekçesini verecektir?

Bu yaklaşıma Touraine'den bağımsız olarak biraz yerleştirdiğimizden gerekçe şahsımızın sayılabilir. En temel önerme, "konuşmak anlamaktır, anlamak konuşmaktır" olmalıdır. Konuşmak ve, dolayısıyla, anlamak veya anlamaya başlamak için konuşulacak kişinin zihni ile bir tür ön iletişim kurmalıyız. Bu ön ilişki; yıllardır süren arkadaşlık, karşılıklı fakat sürekli bakışma, aynı mekanlarda bulunma ya da karşımızdaki insan veya insanlar ile bizi biraraya getiren üçüncü kişilerle birlikte tanışıklık gibi sayısız şekillerde olabilir ve kurulabilir. Bu, "konu ile biz arasında" eskilerin de- 
diği gibi bir "ünsiyet" meydana getirir. Öyle olur ki, bizim ağzımızdan soru formunda veya başka türlü çıkan kelimeler ile, karşımızdaki kişinin zihninde bulunduğunu sezdiğimiz düşünce arasında bağlantı kurulur. Çünkü biliriz ki, insanlar arası iletişim hiçbir zaman tek yönlü olamaz. Hep ve sadece cevap beklemekle kalmayız ve öylece durmayız; bizim vereceğimiz yanıtların biçimi ve içeriği henüz gelmeyen ama gelmesi beklenen veya sezilen karş1lı̆̆a göre şekillenir. Yahut tersinden söylersek; karşımızdakine bir hususta cevap ya da karşılık verirken veya doğrudan kendimiz soru sorarken bazı beklentiler içerisine gireriz. Ancak bu, "karş1mızdakinin vereceği karşılığı biliyoruz" anlamına gelmez. Mamafih, müphem, soyut ve belirsiz de olsa, gelebilecek karşılıkları tasavvur ve tahayyül edebilmemiz gereklidir. Zira, aksi taktirde, "dinleyen pozisyonu"nu da yitirip belki umursamazlıkla suçlanırız. Günlük konuşma dilinde kullandığımız ve böyle durumları belirten bir serzenişin "ben konuşuyorken neredesin?" şeklindeliği boşuna değil. O halde, her konuşma, gündelik hayatta bile, bir "zihne girme ameliyesi"dir. Ancak bu şekilde "mukaleme" meydana gelir. Ne var ki, söylediklerimizle veya sorduklarımızla karşımızdakinin zihnine girebilmemiz yani karşlıklı konuşmayı (mukalemeyi) sürdürebilmemiz için, hemen hatta daha önceden hem bizim hem de karşımızdaki kişinin karşılıklı olarak birbirimizin zihninde bulunmamız gerekli. Bunu bilimsel araştırmalara taşıyı anlayan özne (araştırmacı) tarafından bakarsak denilebilir ki; bir hususu ifade etmek, kelimelere dökmek için başka insanların da "zihnimizde" bulunması zorunludur. "Kelimelere dökme" büyük yönüyle anlama ve yorumlama olduğuna göre; anlama ve yorumlamanın kendi öznelliğimizden kaynaklanmaması için de zorunludur bu. İşte, metinler ile iletişim ve bu iletişimle yaratılan "bilgi"nin diyalektiği budur; ama diyalojiye, "karşılıklı konuşmaya" dönüşür. Kısacası, iletişim ve bilgi; başka söyleyişle "anlama ve yorum" "özneler-arası" bir fenomendir. Biz "özne"yiz, metin de "özne"dir. Metin öznedir, metni ortaya koyan yahut metne dayandığını düşündüğümüz bireyler öznedir ve aradaki iletişimi veya tersini araştıran müdahaleci sosyolog da bir öznedir. Böyle gidince, anket ve diğerlerinin "araştırılan"1 koşullandırma riskinden kaçabilmiş, derin yorumsama yapabilmiş ve "genellemeci açıklamalar"dan kaçınabilmişizdir. Yine; anlamaya çalıştığımız insanları ilişkilendirdiğimiz "Kitap" ve "kitaplar"ın "araştıran özne"yi şartlandırmasını da engelleyebilmişizdir. Hem metnin muhatabı hem de araştırmacı adına, "metin böyle diyor, uygulayıcıları da böyle yapıyor" demekten de kurtulmuşuzdur. Zira durum hiç de öyle olmayabilir. 


\section{Sonuç Yerine}

Çalışmamızın yukarıdaki cümlelerle bitmesini arzu etmezdik aslında. Çünkü, göndermede bulunduğumuz kitaplarımızın "niceliksel yaklaşım"1 reddettiği hatta yerden yere vurduğu izlenimini fırsat bulmuşken burada da kuvvetlendirmiş sanılabiliriz. Hiçbir yerde ve hiçbir zaman böyle bir maksadımız olmadı. Tekebbür gibi algılanacağını tahmin ediyoruz ama, bizim üstümüzden böyle bir yerden yere vurmaya müsaade etmiyoruz. Çalışmanın böyle bitmesi, Touraine'nin kendisi olsun, takipçileri olsun yöntemlerini izah ederlerken hem kalkış noktalarında hem de vardıkları yerde bir şekilde onunla karşıtlama yapmalarındandır. 